\title{
Influence of Nearshore Mining Pits on Hydro- and Lithodynamics of a Dissipative Coastal Zone: Case Study of the Hel Peninsula (Poland)
}

\author{
Rafał Ostrowski, Marek Skaja \\ Institute of Hydro-Engineering, Polish Academy of Sciences, Kościerska 7, 80-328 Gdańsk, Poland, \\ e-mails: rafal.o@ibwpan.gda.pl, mskaja@ibwpan.gda.pl
}

(Received May 04, 2016; revised September 23, 2016)

\begin{abstract}
The paper deals with a sandy shore located on the open sea side of the Hel Peninsula in Poland (the south Baltic Sea coast). The study site displays a cross-shore profile that intensively dissipates wave energy, mostly due to breaking. The theoretical modelling of wave transformation at this site reveals specific distributions of wave heights and bed shear stresses. The sediment borrow areas, presently used and identified for future exploitation, are located inconveniently far from the periodically re-nourished shores. The paper presents the possibilities of dredging works in the coastal zone that would not disturb the natural nearshore motion of water and sediments. The results of the study can be helpful in formulating generic safety standards, at least with respect to dissipative shores of non-tidal or micro-tidal seas, like the Baltic Sea.
\end{abstract}

Key words: cross-shore profile, waves, wave energy dissipation, grain size, bed shear stresses, nearshore mining pits

\section{Introduction}

Similarly to many other European coastal segments (see e.g. EUROSION 2004), the south Baltic sandy shores are subject to erosion at numerous locations and require protection. Among several measures of shore protection against erosion and flooding, artificial nourishment of the shoreface, beach and dune is commonly applied. This worldwide method of coastal defence is relatively inexpensive, flexible, sustainable and, to a great extent, environmentally friendly. To achieve good results, i.e. efficiency and durability, appropriate material ought to be used in nourishment activities. Sand with an optimal grain size distribution is sometimes unavailable in close proximity of the nourished shore segment. In one of extreme cases, sediment for beach nourishment was hauled by truck from over 200 miles away (Douglass 2002). In most cases, however, borrow areas are located at a closer distance, and the dredged material can 
be transported by sea. Dredging operations, however, negatively affect the stability of the shoreline if carried out too close to it (Demir et al 2004). Therefore, offshore sand mining seems always safer to decision-makers. On the other hand, this increases the cost of the entire operation of dredging, transport and nourishment. It becomes more expensive with the growing depth in the dredging area and distance from the shore. In view of the above, it is important to seek a reasonable compromise between minimising the nearshore effects and reducing the total cost of the operation (van Rijn et al 2005).

Artificial shore nourishment with sediments obtained in close vicinity of the shoreline is accepted and practiced in Poland, particularly in shallow nearshore zones with weak hydrodynamic impacts. The shores of the Vistula Lagoon (see Fig. 1 for location), eroded by waves, currents and seasonal ice phenomena, have been successfully nourished by this method for more than 100 years (Podbereski et al 2003). Several years ago, such operations were designed and implemented on the southern shore of the Vistula Lagoon (Kapiński et al 2004). The sand was taken from a superficial bottom layer, $1 \mathrm{~m}$ thick, at a distance of about $300 \mathrm{~m}$ from the shoreline, and transported shorewards. These works were carried out by using a trailing suction dredger and a floating pipeline (see Fig. 2). The sediment, pumped onto the emerged part of the shore, was then distributed by bulldozers.

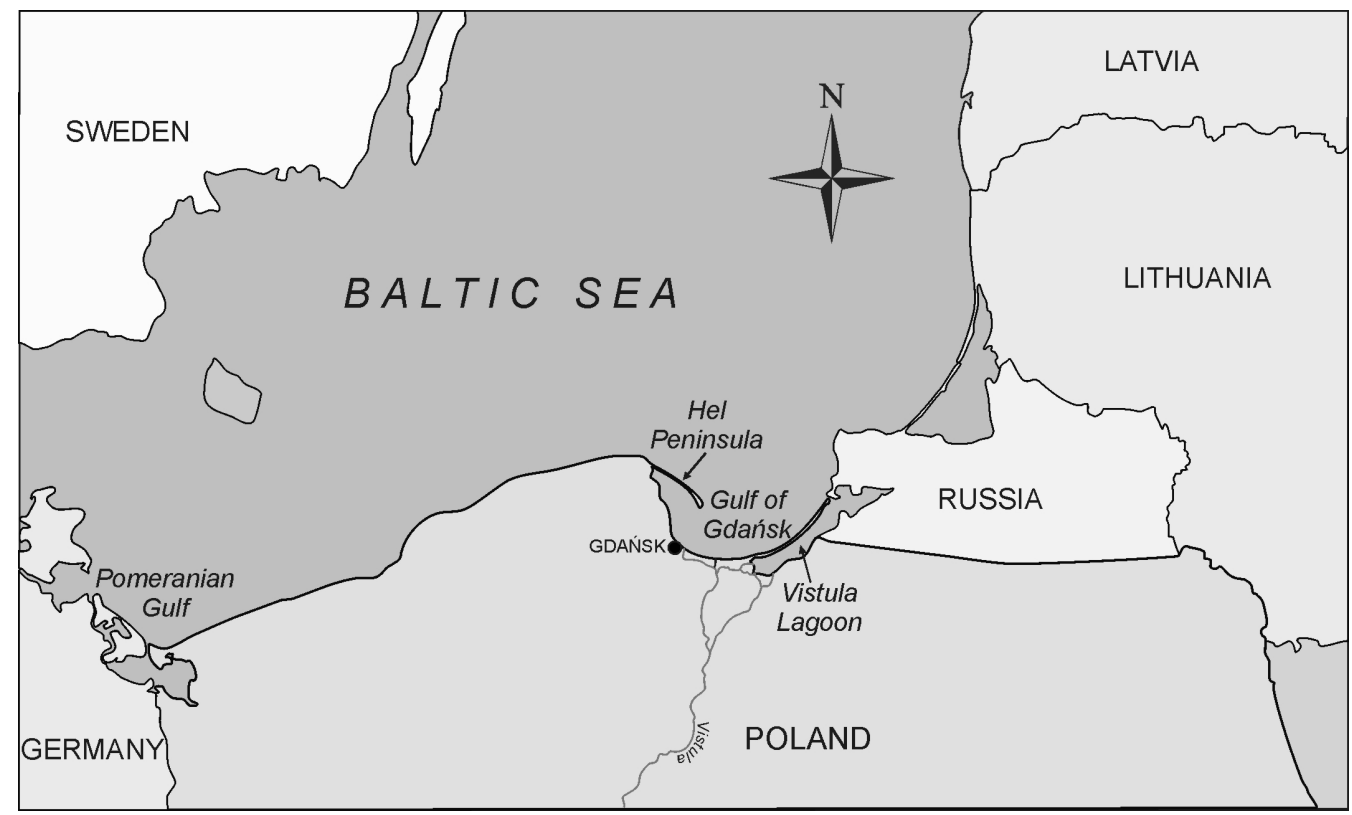

Fig. 1. Location of the Vistula Lagoon and the Hel Peninsula on the south Baltic coast

Similar nourishment schemes were also successfully applied on open sea shores, with sand borrow areas located not much further from the shoreline (Dean 2002). 

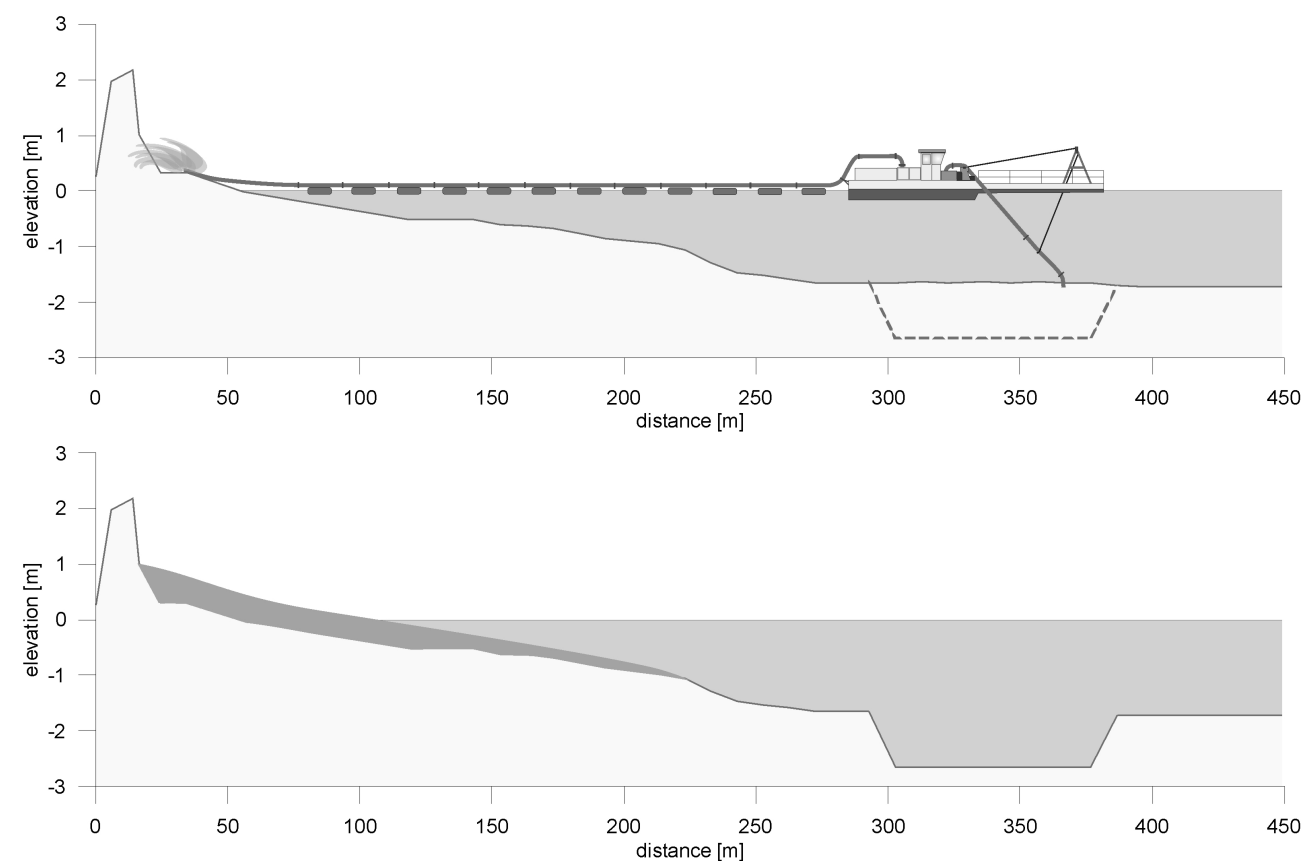

Fig. 2. Artificial shore nourishment in the Vistula Lagoon

For example, artificial nourishment of the Atlantic shore in the United States (Delray Beach, Florida) was carried out with sediments pumped from a borrow area whose shoreward edge was located at a distance of about 7500 feet $(762 \mathrm{~m})$ from the shoreline. The dredging zone was ca. $300 \mathrm{~m}$ wide and stretched ca. $2500 \mathrm{~m}$ along the shore. According to Dean (2002), these parameters were selected to ensure that the borrow area was located between underwater bars. Similarly, artificial shore nourishment in Miami Beach (Florida, the Atlantic coast) was accomplished with material collected from two parallel nearshore zones located between bars. The nourishment of the eighteen-mile Panama City Beach (the Gulf of Mexico, Florida) was done after dredging activities had provided sand from nearby borrow areas, mostly in the form of segmented longshore belts (Dean 2002).

According to Dean's (2002) recommendations, borrow holes should be located in a reasonable proximity to the shoreline, namely in a zone of sufficiently large depths where "significant sand transport will not be induced into the pit by its presence nor normal onshore sand transport will be interrupted". This implies that a mining pit located very close to the shoreline can cause both an outflow of sediment from the freshly nourished beach and the trapping of sand transported within the natural seasonal onshore sediment flux. The possibility and intensity of such impacts depend on the geometrical parameters of the excavation, including its depth and location on the cross-shore profile, hydrodynamic forcing, grain size distribution and the features of benthic communities (Hitchcock and Bell 2004). 
Sand mining excavations influence wave transformation in the coastal zone. Bathymetric changes caused by dredging activities can considerably affect wave refraction, diffraction, reflection and interference, as well as wave energy dissipation. For instance, wave refraction over two deep sand mining pits in the nearshore zone of Grand Isle (Louisiana) resulted in the appearance of two vast accumulative forms (salients) and three erosive spots compensating this accumulation (Dean 2002).

It should be expected, however, that nearshore mining pits can mostly affect the wave energy dissipation process, particularly under the bathymetric conditions of the Hel Peninsula (see Fig. 1 for location), characterised by a mild inclination of the nearshore sea bottom, namely from $1 \%$ to $2 \%$. Such a shore almost does not reflect waves, and the wave transformation process is dominated by wave energy dissipation, mainly due to breaking (Pruszak et al 2008, Ostrowski et al 2010). Multiple wave breaking is observed in the multi-bar coastal zone. As a result, a small amount of deep-water wave energy reaches the shoreline vicinity (Kaczmarek et al 2005). Therefore, all dredging works in such coastal zones, including the Hel Peninsula shores and many other south Baltic coastal segments, ought to be organised in such a way as to protect the nearshore sea bed forms that are favourable to wave energy dissipation. Underwater bars and nearshore reefs are examples of such forms. One cannot agree to dredging solutions which would result e.g. in rapid sedimentation in the mining pits at the cost of erosion of the nearby bars if these bars play an important role in wave energy dissipation.

In view of the above, it is worthwhile to seek an unsophisticated method of determining whether the planned nearshore dredging and the resulting mining pits will negatively affect hydrodynamic and lithodynamic processes. This method can be generic to some extent, at least with respect to the dissipative shores of non-tidal or micro-tidal seas, like the Baltic Sea. The present study is an attempt to propose such a method.

\section{Study Site and Data}

Shore protection is of utmost importance for the Hel Peninsula. Permanently inhabited by about 10000 people, the peninsula is visited by more than 1 million tourists every year. With an area of about $32 \mathrm{~km}^{2}$, the peninsula has a population density of ca. 313 inhabitants per square kilometre, which is considerably more than the average in Poland (123 persons $/ \mathrm{km}^{2}$ in 2011). The communications between two towns (Hel and Jastarnia) and 3 villages of the Hel Peninsula and Władysławowo, located at its root (Fig. 3), are provided by one road and one railway line, which not only serve tourists and local inhabitants, but are also the only supply lines for numerous institutions and enterprises operating on the peninsula. Coastal erosive phenomena, which have been observed since the 1940s, constitute a serious threat to these supply lines and other facilities located in the vicinity of the shoreline.

On the strength of the Act of Parliament of the Republic of Poland (28 March 2003) on the establishment of a long-term 'Coastal Protection Programme', the safe 


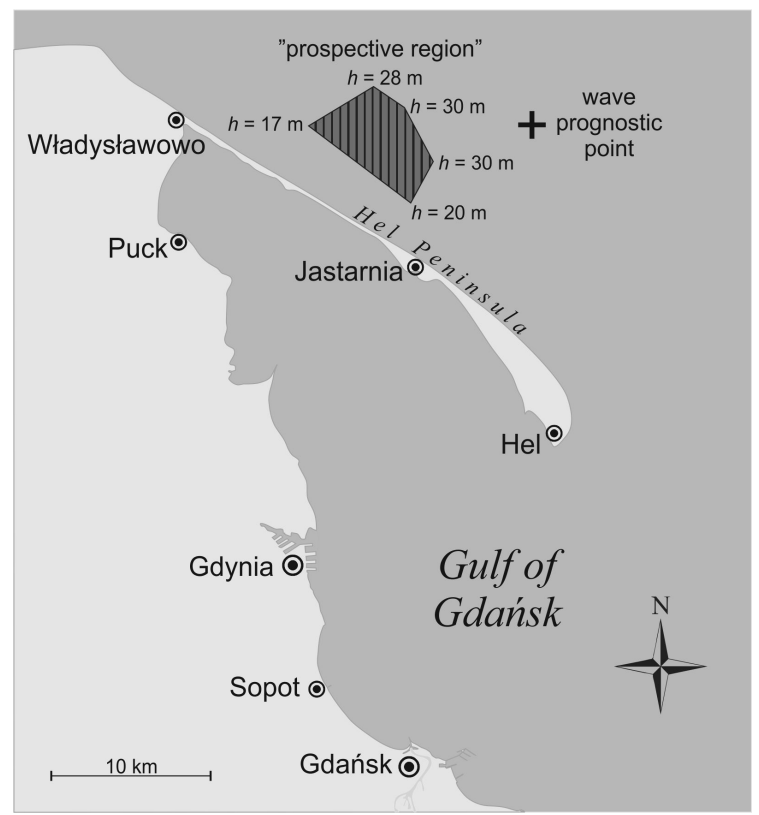

Fig. 3. Location of the "prospective region" of sediment borrow areas for the nourishment of the Hel Peninsula and the deep-water wave prognostic point $(+)$

maintenance of the shores of the Hel Peninsula on the open sea side is provided by a system of sediment bypassing at the harbour of Władysławowo and beach nourishment on its lee side. Some other shore segments of the Hel Peninsula, stretching $23.5 \mathrm{~km}$ south-eastwards from Władysławowo, are also nourished by artificial beach fills. The material for nourishment is acquired at offshore locations, at depths of about $15-25 \mathrm{~m}$. The sediment is transported towards the nourished sites by a hopper dredger and pumped onto the beach as a water-soil mixture by a $500 \mathrm{~m}$ long pipeline laid on the sea bed, perpendicularly to the shoreline. The sand is deposited on the emerged part of the shore, and the proper beach shape is formed by bulldozers. These operations are well organised and quite effective, but the actual needs appear to be greater than those anticipated in the 'Coastal Protection Programme'.

Elaborated in 2011 by the Polish Geological Institute and the Maritime Institute in Gdańsk for the Maritime Office in Gdynia (a governmental agency whose responsibilities include coastal management), the geological-bathymetric documentation contains a detailed specification of future sediment borrow places located near the Hel Peninsula in the "prospective region", having an area of $33.33 \mathrm{~km}^{2}$, at depths $h$ of 17-30 m (see Fig. 3).

The sediment borrow places were determined as a result of extensive field surveys and laboratory analyses, in which hundreds of sea bed samples were tested. The landward boundary of the "prospective region" runs at a distance of 2.7-3.3 km from the shoreline, whereas its seaward boundary is located $5.7-7.9 \mathrm{~km}$ offshore. 
The "prospective region" stretches $8 \mathrm{~km}$ along the shore, approximately $7.5-15.5 \mathrm{~km}$ from the root of the Hel Peninsula (Fig. 3). In this region, there is a continuous layer of sandy sediments having a thickness from $0.7 \mathrm{~m}$ to more than 10 .

It has been found that at least 6 million $\mathrm{m}^{3}$ of sandy sediments having appropriate grain size distributions for the Hel Peninsula nourishment are theoretically available in 6 subareas of the "prospective region", at depths of ca. 15-25 m. In practice, one can count on obtaining no more than 5 million $\mathrm{m}^{3}$. This amount is expected to satisfy the needs of the Hel Peninsula shore nourishment by 2020. It may well be sufficient because slightly above 3.5 million $\mathrm{m}^{3}$ was used for this purpose in the period from 2003 to 2010. One should bear in mind, however, that in view of anticipated climate changes, resulting in intensification of wave impacts, nourishment volumes will have to be increased. Moreover, after exhaustion of sediment resources in the "prospective region", it will become necessary to search for other remote deposits of sediments having appropriate grain sizes. Nearshore borrow areas at the Hel Peninsula have never been taken into account.

In this situation, it is certainly worth considering sediment stocks available closer to the shoreline, in direct vicinity of the beaches requiring artificial nourishment. Dredging at such locations will be possible if safety standards with respect to the shore stability are satisfied. To determine these standards, wave impact on the nearshore sea bed ought to be analysed.

The offshore wave climate was determined on the basis of the numerical prognostic wave model WAM4 (WAMDI Group 1988), in which the input comes from meteorological (wind and air pressure) fields. Several years ago, the spectral wave model WAM4 was used under the HIPOCAS project (coordinated by HZG, former GKSS, Germany), aimed at reconstructing the long-term European wave climate from 1958 to 2001. The reconstruction procedure is described in detail by Weisse et al (2009). In brief, a global reanalysis by the National Centre for Environmental Prediction National Centre for Atmospheric Research (NCEP - NCAR) (Kalnay et al 1996) was applied in combination with the spectral nudging technique (von Storch et al 2000) as the forcing to the REgional Climate MOdel (REMO), which is based on the numerical weather prediction model EM of the German Weather Forecast Service (DWD), (Feser et al 2001). In this way, wind parameters (velocity and direction) at a height of $10 \mathrm{~m}$ above the sea and pressure fields were obtained. The results from the REMO model were subsequently used in the WAM4 model.

The WAM4 model is based on a so-called wave action balance equation and takes into account the energy transfer from wind to the sea, "white-capping" wave breaking, bottom friction, and resonance interactions of wave components. For the reconstruction of Baltic waves, the model resolution of the spatial grid was $5^{\prime} \times 5^{\prime}$ (angular minutes). The model time step of the input wind data was set to 1 hour. This input was then interpolated, which yielded a computational resolution of $300 \mathrm{~s}$. At each grid point for every hour of the 44-year-long reconstruction period, the computational results com- 
prised the following representative wave parameters: significant wave height, wave period, and wave ray direction.

The results of the wave climate reconstruction (1958-2001) described above were used to determine offshore wave parameters for the Hel Peninsula. A deep-water wave prognostic point was chosen to represent waves coming from directions favourable for the largest wind fetch, namely the N-NE sector (the analysis had shown that the waves approaching the site from the other directions were smaller). Such a representative wave prognostic point is located $13 \mathrm{~km}$ north-east of the central part of the Hel Peninsula (Fig. 3).

\section{Wave Transformation and Bed Shear Stresses: Methods Applied}

The greater the water depth, the less intensive the wave impact on the sea bed. At a certain water depth, waves with given parameters do not affect bottom sediments. For extreme stormy wave conditions, this boundary depth is conventionally called the depth of closure. At depths greater than the depth of closure, there is no motion of sediments or this motion is very weak. Its value can be determined by simple equations proposed by Hallermeier and Birkemeier in the 1970s and 1980s (Dean 2002). According to these equations, the depth of closure can be calculated on the basis of the parameters of extremely high waves, namely the waves having the significant wave height $H_{s}$ which is exceeded only 12 hours per year, or only $0.14 \%$ of the time.

A more precise determination of the sediment transport regime (motion of single grains or intensive transport, up to the sheet flow) is possible by calculating the Shields parameter, representing the dimensionless bed shear stress and given by the following formula (see e.g. Nielsen 2009):

$$
\theta=\frac{u_{f}^{2}}{(s-1) g d},
$$

in which $u_{f}$ is the friction velocity, $s$ is the ratio of sea bed soil density to water density ( $s=\rho_{s} / \rho$, equal to about 2.65 for quartz sand), $g$ is acceleration due to gravity and $d$ is the sea bed grain diameter.

The determination of the friction velocity $u_{f}$ is a complex task. The friction velocity represents the bead shear stress $\tau$ (defined as $\tau=\rho u_{f}^{2}$ ), which is the main driving force of sediment transport. According to the basic fluid mechanics, the bed shear stress $\tau$ depends of the water flow velocity at the top of the bed boundary layer and the sea bottom roughness. The sea bed, if built of sandy sediments, becomes moveable under hydrodynamic impacts (resulting from waves and currents), which causes additional difficulties in the theoretical solution leading to the determination of the friction velocity $u_{f}$. Due to the above, according to Nielsen (2009), it is worth resorting to a simplified approach which deals with the wave-related bed roughness concerning sand grains only ("skin" bed roughness) and neglecting the bed roughness resulting from the presence of bed forms (ripple bed roughness). Such an assumption 
is justified for a flat bed or weakly developed bottom ripples (sediment motion of small intensity) and for very intensive sediment transport during which bed forms are washed away (sheet flow). The dimensionless bed shear stress for the situation of "skin" bottom friction, related to a "skin" roughness height of $2.5 \mathrm{~d}$, can be determined by the following equation (Nielsen 2009):

$$
\theta_{2.5}=\frac{1}{2} f_{2.5} \frac{\left(a_{1 m} \omega\right)^{2}}{(s-1) g d},
$$

in which:

$$
f_{2.5}=\exp \left[5.5\left(\frac{2.5 d}{a_{1 m}}\right)^{0.2}-6.3\right],
$$

where $\omega$ denotes angular frequency in the wave motion, $a_{1 m}=U_{1 m} / \omega$ (amplitude of the nearbed oscillatory flow), and $U_{1 m}$ is the maximum nearbed (free stream) oscillatory velocity (for sinusoidal waves, $U(\omega t)=U_{1 m} \sin (\omega t)$ ).

As a condition for the initial motion of single grains, the value $\theta_{2.5}=0.05$ is usually assumed. For $\theta_{2.5}$ equal to $0.2-0.3$, a more intensive motion of sea bed grains and developed bottom ripples are observed. Under more intensive hydrodynamic impacts, characterised by $\theta_{2.5}$ amounting to $0.8-1.0$, the ripple marks are washed away, and the sheet flow appears.

Knowing the values of the dimensionless shear stress $\theta_{2.5}$ on the cross-shore profile, one can determine the sediment transport regime at an arbitrary location. This can be done for both a natural sea shore profile and a coastal transect displaying results of anthropogenic interventions, e.g. mining pits. The calculation of $\theta_{2.5}$ by Eqs. (2) and (3) requires an earlier determination of wave parameters on the cross-shore profile.

The wave transformation process can be modelled by any reliable theoretical approach. In the present study, we use the classical model proposed by Battjes and Janssen (1978), subsequently adapted for an arbitrary (also multi-bar) cross-shore shape (Szmytkiewicz 1996, 2002a, 2002b). The model is based on the phase-averaged approach. The wave transformation process with multiple wave breaking can be modelled for an arbitrary angle of deep-water waves. Following Battjes and Janssen (1978), it is assumed that the waves are random and that their heights in the entire coastal zone can be described by a Rayleigh distribution. On the basis of experimental investigations and other available data, it may be deduced that this rough assumption can lead to inaccuracies of no more than $10 \%$ in the determination of wave height in a nearshore zone. Under the assumption that there are no wave reflections from the shore, the wave height is computed from the equation of energy flux conservation, which is a simplified form of the wave action equation. The wave energy dissipation is determined with the assumption that the dissipation is related to the wave breaking process only. Bottom friction, constituting the other form of wave energy dissipation, is assumed to be negligibly small, which is in agreement with some experimental assessments by Szmytkiewicz (2002b). 
This approach, based on the modelling of wave transformation and on the calculation of the dimensionless shear stress $\theta_{2.5}$, has been successfully applied in previous studies dealing with wave-induced sediment motion regimes at various locations in the coastal zone, see e.g. Cerkowniak et al (2015).

\section{Computational Results and Discussion}

The computations of the variability of the wave height $H$ and the dimensionless shear stress $\theta_{2.5}$ were carried out for an actual bathymetric cross-shore transect of the Hel Peninsula located $11.5 \mathrm{~km}$ from its root (about one third of the peninsula length). The grain diameter was assumed as $d=0.2 \mathrm{~mm}$, equal to the actual median grain diameter found in soil samples collected at the study site.

First, the modelling system was run for an extreme storm having a return period of 10 years. The offshore wave parameters at the prognostic point (see Fig. 3) read: the significant wave height $H_{s}=6.27 \mathrm{~m}$ and the wave energy peak period $T_{p}=12 \mathrm{~s}$. The waves were assumed to approach the shore perpendicularly, namely from the N-NE sector, which constituted the most unfavourable situation. The computations comprised six schemes: the natural bathymetric shape and the cross-shore profile with an assumed mining pit ( $2 \mathrm{~m}$ deep and $200 \mathrm{~m}$ wide) situated at five locations corresponding to various water depths. The results of these computations are shown in Fig. 4.

It can be seen in Fig. 4 that none of the excavations has a distinct influence on the wave transformation process and wave energy dissipation. Distributions of the significant wave height $H_{s}$ for the cross-shore transect with the mining pits located relatively far from the shore $(1000-5000 \mathrm{~m})$, at depths of $12-20 \mathrm{~m}$, are the same as for the natural sea bed profile. The dimensionless bed shear stresses $\theta_{2.5}$, having values from less than 1.0 at a distance of $6 \mathrm{~km}$ offshore to 2.0 in the zone stretching 300-700 $\mathrm{m}$ from the shoreline, indicate intensive sediment transport along the entire shore transect. There is a slight reduction in $\theta_{2.5}$ in the excavations (increasing depth reduces the wave impact on the bottom), but, nevertheless, the sheet flow is found in the entire coastal zone under consideration.

Analogous calculations were next carried out for a case in which the natural shore profile has been modified by dredging, resulting in the disappearance of the offshore (outer) bar located originally at a distance of 1000-1600 m from the shoreline. In this numerical simulation, the material taken from the bar is used for artificial nourishment of the shoreface, i.e. the region lying landwards of the nearshore (inner) bar, see Fig. 5 .

Figure 5 shows that the wave height slightly increases landwards of the dredged area (600-1200 $\mathrm{m}$ from the shoreline) and remarkably decreases close to the shoreline, on the nourished beach and shoreface. The induction of ultimate wave energy dissipation further from the shoreline is desirable in terms of sediment stability in direct vicinity of the shoreline. The change in bed shear stresses in the zone up to 100 $\mathrm{m}$ from the shoreline also seems favourable, displaying a reduction in the maximum 




Fig. 4. Calculated distributions of significant wave height $H_{s}$ and dimensionless bed shear stress $\theta_{2.5}$ on the Hel Peninsula cross-shore profile for 10-year storm conditions: the natural profile (solid line) and the profile with a mining pit at various locations (dashed and dotted lines)



Fig. 5. Calculated distributions of significant wave height $H_{s}$ and dimensionless bed shear stress $\theta_{2.5}$ on the Hel Peninsula cross-shore profile for 10-year storm conditions: the natural profile (solid line) and a profile with the shoreface nourished with sediment taken from the offshore bar (dashed line) 
value from 1.5 to 0.9 . For both the natural and the modified sea bed profiles, the dimensionless shear stress $\theta_{2.5}$ amounts to about 1.4 at a distance of $2000 \mathrm{~m}$ offshore, and the maxima attain values of about 2.0 at distances of 300-600 m from the shoreline. In presence of the nourished shore, $\theta_{2.4}$ appears to be greater than for the original bottom profile in the zone 100-180 $\mathrm{m}$ from the shoreline. Obviously, the values of $\theta_{2.5}$ decrease in the sand borrow area (the offshore bar).

If dredging activities were carried out at the offshore bar, and the sandy material was used for nourishment of another shore segment, the nearshore processes at the transect under consideration would not change. The results of modelling such a case are presented in Fig. 6.

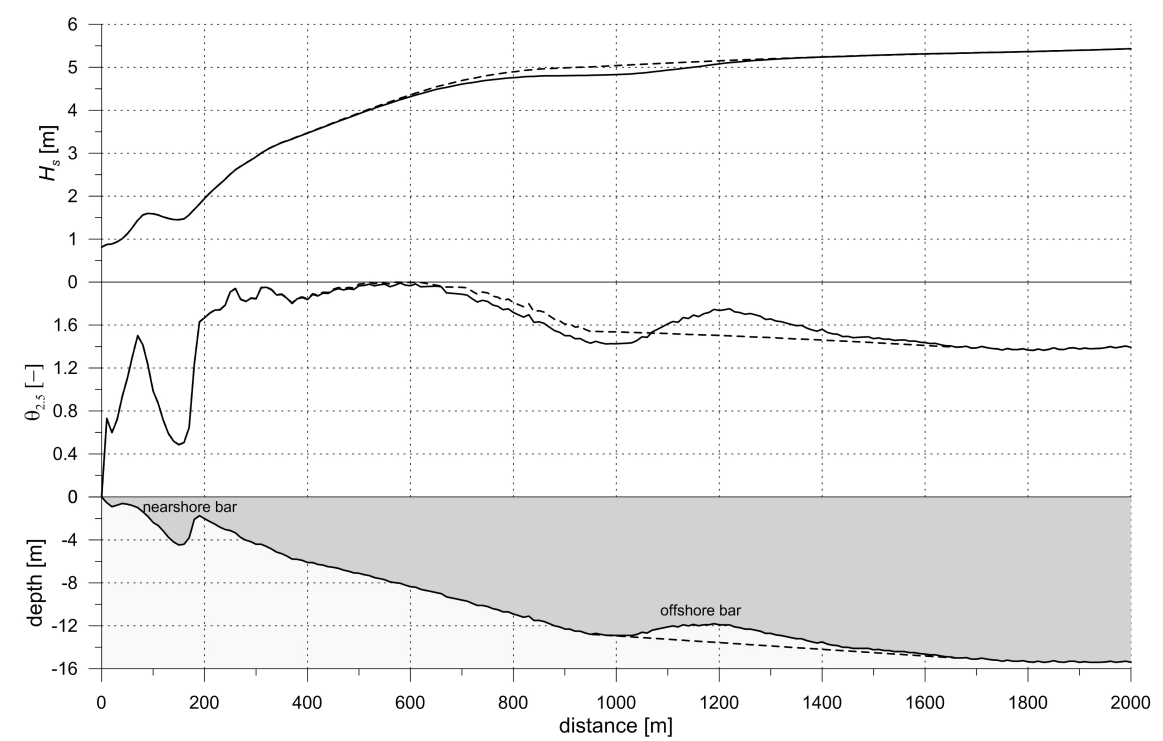

Fig. 6. Calculated distributions of significant wave height $H_{s}$ and dimensionless bed shear stress $\theta_{2.5}$ on the Hel Peninsula cross-shore profile for 10-year storm conditions: the natural profile (solid line) and a profile without the offshore bar (dashed line)

It can be seen in Fig. 6 that the wave energy and bed shear stresses under the extreme storm conditions will not change in the nearshore zone, i.e. at distances smaller than $600 \mathrm{~m}$ from the shoreline, in comparison to the hydrodynamic situation on the natural shore profile. Similarly to the previous case (cf. Fig. 5), the intensity of lithodynamic processes will slightly increase at a distance of 600-1050 $\mathrm{m}$ from the shoreline and decrease further seawards, in the sand borrow area (the offshore bar).

It can be concluded that any dredging works at depths of about $12 \mathrm{~m}$ and more will not influence the nearshore wave impact and nearshore lithodynamic processes at the study site if the sea bottom in the shoreline vicinity remains untouched (Figures 4 and 6). Moreover, the calculated bed shear stresses for the extreme 10-year storm conditions indicate quite an intensive motion of sediment at the mining spots. This will 
create conditions favourable to the gradual silting up of these underwater excavations and to a long-run recovery of the offshore bar from which the sediment is mined.

The computational results presented in Figures 4, 5 and 6 concern extreme conditions occurring during the 10-year storm. According to the depth of closure concept, the representative hydrodynamic impact on the shore is associated with the extreme 1 -year storm. Assuming milder wave conditions, borrow areas closer to the shore, at depths smaller than $12 \mathrm{~m}$, might be considered.

The results of computations for the natural profile and a profile with an excavation $200 \mathrm{~m}$ wide and $2 \mathrm{~m}$ deep (600-800 $\mathrm{m}$ from the shoreline, at a depth of $8-11 \mathrm{~m}$ ) for 1-year storm conditions $\left(H_{s}=3.13 \mathrm{~m}, T_{p}=8 \mathrm{~s}\right)$ are shown in Fig. 7. As before, the most unfavourable situation was assumed, in which waves approach the shore perpendicularly.

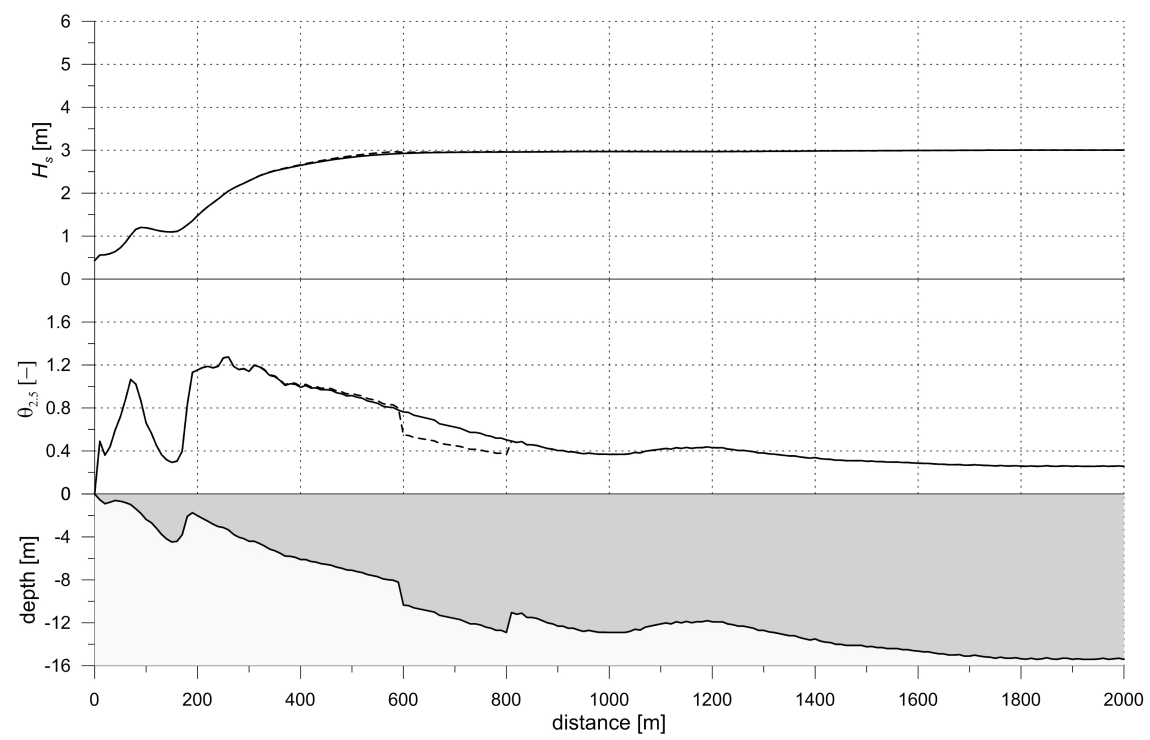

Fig. 7. Calculated distributions of significant wave height $H_{s}$ and dimensionless bed shear stress $\theta_{2.5}$ on the Hel Peninsula cross-shore profile for 1-year storm conditions: the natural profile (solid line) and a profile with a mining pit at a depth of $8-11 \mathrm{~m}, 600-800 \mathrm{~m}$ from the shoreline (dashed line)

The results of computations presented in Fig. 7 show no effect of the borrow hole on the wave energy dissipation process (wave height $H_{s}$ ) and the sand motion driving force (shear stress $\theta_{2.5}$ ) in the nearshore region between the excavation and the shoreline. It should be pointed out that seawards of the excavation, $\theta_{2.5}$ values imply a moderately intensive sediment motion (the seabed ripple flow regime). Thus, the borrow area in this case is located at a depth greater than the depth of closure, without negative consequences for the nearshore seabed and shore stability.

In the nearshore zone, the bed shear stresses $\theta_{2.5}$ are considerable, locally having values above 1.0. This certainly denotes sheet flow conditions, under which intensive 
sea bed changes can take place. However, the sea bed evolution for the cross-shore profile with the mining pit will occur in the same way as in the case of the natural sea bottom profile. One can expect differences only at the excavation itself, which will presumably be subject to silting up at the cost of the erosion of its edges and the adjacent sea bed. The anticipated bottom changes will have no visible impact on wave transformation and energy dissipation. For the storm parameters under consideration, these processes take place mostly at depths of $2-6 \mathrm{~m}(7 \mathrm{~m}$ at the maximum), i.e. at a distance of $200-400 \mathrm{~m}$ from the shoreline (500 $\mathrm{m}$ at the maximum). Hence, the mining pit remains beyond the depth of closure point.

There can be a doubt whether the wave conditions with a return period of 1 year are more appropriate to assume than the 10-year (or 100-year) conditions, which definitely cause more severe coastal changes. On the other hand, there are no clear hints concerning the design return period in nourishment planning. An artificial beach (or shoreface) is not a permanent shore protection measure, and its nature and effectiveness require periodic renourishment operations. Therefore, all decision support systems and approaches allow for a significant loss of sediment not only on a multi-year scale but even over a single year. This line of thought leads to the conclusion that in cases of many dissipative sea shores, the criterion of the 1-year return period can constitute a safety standard for nearshore sand mining.

In the absence of precise recommendations, the maritime authorities responsible for coastal management are in a difficult position when searching for optimal sediment borrow areas. Exaggerated caution in selecting remote offshore mining spots by the engineer's intuition, results in unnecessarily high costs. On a second front, dredging in the nearshore zone to reduce these costs is always risky.

\section{Final Remarks and Conclusions}

Both Polish and foreign shore protection experiences, as well as Polish regulations, explicitly indicate that artificial nourishment will remain the basic method of coastal defence against erosion and flooding. This particularly concerns the Hel Peninsula shores, requiring beach fills with a few hundred thousand cubic metres of sediment per year. In view of the observed climate changes and the growing human pressure on the coast of the Hel Peninsula, the coastal managers will have to increase the amount of sand used for the nourishment and reduce the cost of nourishment operations. This can be achieved only by undertaking dredging activities in the nearshore zone, at an optimal distance from the shoreline beyond the depth of closure point. This innovation would shorten the sand transportation distance by several kilometres, as the "prospective region" stretches from ca. 3-4 km to ca. 7-9 km offshore. The concept of dredging-nourishment operations on the Hel Peninsula shore is depicted in Figures 8 and 9 .

It can be concluded, on the basis of rather scarce information available in publications, that very few dredging-nourishment operations have been carried out according 




Fig. 8. Optimized scheme of artificial shore nourishment on the Hel Peninsula - sectional view



Fig. 9. Optimized scheme of artificial shore nourishment on the Hel Peninsula - top view

to the scheme presented in Figures 8 and 9. This situation obviously results from serious fears that nearshore dredging may endanger coastal stability. The present results allow us to advance the following thesis, valid at least for dissipative sea shores: artificial shore nourishment with material acquired in a nearshore borrow area will not cause negative consequences if the area has been selected on the basis of thorough investigations. These investigations ought to be carried out separately for specific coastal segments, taking into account the wave climate and the coastal bottom profile.

It should be pointed out that the availability of appropriately grain-sized sand in such nearshore regions remains the fundamental issue. The optimal locations of mining spots determined by the modelling of hydrodynamic processes may prove 
impractical if the grain size distributions of the local sea bed sediments are unsuitable. In such a case, the sediment for nourishment has to be supplied from more remote locations.

The approach applied in the present paper to the study site on the Hel Peninsula can be assumed as generic and used for any sea shore worldwide. It can be helpful in determining where lithodynamic processes may evolve negatively after the appearance of mining pits. This approach may also be used to identify whether and how quickly the borrow holes will be silted up, yielding the opportunity for re-nourishment operations according to the same or similar scheme. Certainly, such studies ought to take account of local, site-specific conditions, such as deep-water wave parameters, the cross-shore profile shape and sand grain diameters, as well as the nourishment/dredging needs and planned dimensions of the excavations.

\section{Acknowledgements}

The study was sponsored by the Ministry of Science and Higher Education, Poland under mission-related programme no. 2 of IBW PAN. The authors also acknowledge support from the European Commission through FP7.2009-1, contract 244104 - THESEUS ("Innovative technologies for safer European coasts in a changing climate").

\section{References}

Battjes J. A., Janssen J. P. F. M. (1978) Energy loss and set-up due to breaking of random waves, Proc. $16^{\text {th }}$ ICCE, Vol. I, 569-587.

Cerkowniak G. R., Ostrowski R., Stella M. (2015) Wave-induced sediment motion beyond the surf zone: case study of Lubiatowo (Poland), Archives of Hydro-Engineering \& Environmental Mechanics, 62 (1-2), 27-39.

Dean R. G. (2002) Beach Nourishment. Theory and Practice, Advanced Series on Ocean Engineering - Volume 18, World Scientific Publishing Co. Pte. Ltd., 399 pp.

Demir H., Otay E. N., Work P. A., Borekci O. S. (2004) Impacts of dredging on shoreline change. Journal of Waterway, Port, Coastal and Ocean Engineering, 130 (4), 170-178.

Douglass S. L. (2002) Saving America's Beaches. The Causes of and Solutions to Beach Erosion, Advanced Series on Ocean Engineering - Volume 19, World Scientific Publishing Co. Pte. Ltd., 91 pp.

EUROSION (2004) Living with coastal erosion in Europe. Sediment and space for sustainability, Results from EUROSION study, Luxembourg: Office for Official Publications of the European Communities, http://www.eurosion.org/project/eurosion_en.pdf.

Feser F., Weisse R., von Storch H. (2001) Multi-decadal atmospheric modelling for Europe yields multi-purpose data, Eos Trans AGU, 82 (28), 305-310.

Hitchcock D., Bell S. (2004) Physical Impacts of Marine Aggregate Dredging on Seabed Resources in Coastal Deposits, Journal of Coastal Research, 20 (1), 101-114.

Kaczmarek L. M., Ostrowski R., Pruszak Z., Różyński G. (2005) Selected problems of sediment transport and morphodynamics of a multi-bar nearshore zone, Estuarine, Coastal and Shelf Science, Elsevier Science B.V., 62, 415-425. 
Kalnay E., Kanamitsu M., Kistler R., Collins W., Deaven D., Gandin L., Iredell M., Saha S., White G., Woollen J., Zhu Y., Chelliah M., Ebisuzaki W., Higgins W., Janowiak J., Mo K. C., Ropelewski C., Wang J., Leetmaa A., Reynolds R., Jenne R., Joseph D. (1996) The NCEP/NCAR 40-Year Reanalysis Project, Bull. Amer. Meteor. Soc., 77 (3), 437-471.

Kapiński J., Ostrowski R., Piotrowska D., Różyński R., Skaja M., Szmytkiewicz M. (2004) Assessment of the shore condition and executive recommendations on artificial nourishment aimed at reconstruction of the dike foreground in Kadyny (ZW km 30.4-30.8) and the railway tracks in the region of Tolkmicko (ZW km 22.6-23.6), expert opinion C2-9/2004, IBW PAN, Gdańsk, 16 pp. (in Polish).

Nielsen P. (2009) Coastal and Estuarine Processes, Advanced Series on Ocean Engineering - Volume 29, World Scientific Publishing Co. Pte. Ltd., 343 pp.

Ostrowski R., Pruszak Z., Skaja M., Szmytkiewicz M., Trifonova E., Keremedchiev S., Andreeva N. (2010) Hydrodynamics and Lithodynamics of Dissipative and Reflective Shores in View of Field Investigations, Archives of Hydro-Engineering \& Environmental Mechanics, 57 (3-4), 219-241.

Pruszak Z., Szmytkiewicz P., Ostrowski R., Skaja M., Szmytkiewicz M. (2008) Shallow-water wave energy dissipation in a multi-bar coastal zone, Oceanologia, 50 (1), 43-58.

Podbereski B., Dubrawski R., Cieślak P. (2003) Documentation concerning the maintenance nourishment of the dike foreground in Krynica Morska at km ZW 84.4-87.3, WUPROHYD Sp. z o.o., Gdynia (in Polish).

Szmytkiewicz M. (1996) 2D velocity distributions in nearshore currents, Proc. Coastal Dynamics '95, ASCE, New York, 366-376.

Szmytkiewicz M. (2002a) Wave-induced currents in the coastal zone, IBW PAN Publishers, Gdańsk, 235 pp. (in Polish).

Szmytkiewicz M. (2002b) Quasi 3D model of wave-induced currents in coastal zone, Archives of Hydro-Engineering \& Environmental Mechanics, 49 (1), 57-81.

van Rijn L., Soulsby R., Hoekstra P., Davies A. G. (2005) SANDPIT, Sand Transport and Morphology of Offshore Mining Pits, Aqua Publications, The Netherlands, $156 \mathrm{pp}$.

von Storch H., Langenberg H., Feser F. (2000) A spectral nudging technique for dynamical downscaling purposes, Mon. Weather Rev., 128, 3664-3673.

WAMDI Group (1988) The WAM model - A Third Generation Ocean Wave Prediction Model, J. Phys. Oceanography, 18, 1776-1810.

Weisse R., von Storch H., Callies U., Chrastansky A., Feser F., Grabemann I., Günther H., Plüss A., Stoye T., Tellkamp J., Winterfeldt J., Woth K. (2009) Regional meteorological-marine reanalyses and climate change projections. Results for Northern Europe and potential for coastal and offshore applications, Bull. Amer. Meteor. Soc., 90 (6), 849-860. 